\title{
Recurrent Mastitis after Core Needle Biopsy: Case Report of an Unusual Complication after Core Needle Biopsy of a Phyllodes Tumor
}

\author{
Nikola Kasprowicz ${ }^{\mathrm{a}} \quad$ Gerd J. Bauerschmitz $^{\mathrm{a}} \quad$ Alexandra Schönherr $^{\mathrm{a}}$ \\ Stephan E. Baldus ${ }^{b}$ Wolfgang Janni ${ }^{\mathrm{a}}$ Svjetlana Mohrmann ${ }^{\mathrm{a}}$
}

${ }^{a}$ Breast Center, Department of Gynecology and Obstetrics, 'Institute of Pathology, Düsseldorf University Hospital, Germany

\section{Keywords}

Core needle biopsy · Complication - Mastitis .

Phyllodes tumor

\section{Summary}

Background: In the routine work-up of suspect breast lesions, ultrasound-controlled core needle biopsy (CNB) is the most common tool to acquire tissue for histopathologic analysis in a safe, quick and convenient way. Complications are generally rare. The most common complications are hematoma and infection, each with less than 1 in 1000 cases. Case Report: Here, we present a case of a 48-year-old patient who underwent CNB for several lesions that were assessed as Breast Imaging Report and Data System (BI-RADS) IV in breast ultrasound and mammography. In the past, she had had 2 bilateral breast reduction surgeries and 1 open biopsy of a fibroadenoma. Histology revealed a phyllodes tumor. Following this, mastitis occurred which was resistant to common conservative measurements such as intravenous antibiotics over months. Finally, mastectomy was performed, followed by adequate wound healing. Conclusions: In the presented case, the prolonged course of breast infection after CNB was not as expected. If this occurs, conservative treatment with antibiotics can be initiated. Possible additional risk factors such as diabetes mellitus, steroid therapy, or immunosuppression should be identified. However, in case of missing recovery, wide surgical excision is recommended.

\section{Introduction}

Percutaneous ultrasound (US)-guided core needle biopsy $(\mathrm{CNB})$ has been established as a standard procedure in the

\section{Schlüsselwörter \\ Stanzbiopsie $\cdot$ Komplikation · Mastitis · Phylloidestumor}

\section{Zusammenfassung}

Hintergrund: Zur Abklärung von auffälligen sonographischen Befunden in der Brust gehört in der Hauptsache die Stanzbiopsie. Sie stellt eine bequeme, schnelle und komplikationsarme Methode zur Asservierung von Gewebe zur histopathologischen Diagnosesicherung dar. In sehr seltenen Fällen (weniger als 1/1000) treten Nebenwirkungen wie Hämatome oder Infektionen auf, die in aller Regel gut behandelbar sind. Fallbericht: Wir möchten hier den Fall einer 48-jährigen Patientin schildern, die aufgrund eines Breast Imaging Report and Data System (BI-RADS) IV-begutachteten mammasonographischen Befundes eine Stanzbiopsie erhalten hat. In der Vergangenheit wurden bei der Patientin bereits 2 Operationen zur Brustreduktion sowie 1 offene Probeexzision bei einem Fibroadenom durchgeführt. Nach der Biopsie entwickelte die Patientin eine therapierefraktäre Mastitis, die über Monate trotz intensiver konservativer Maßnahmen wie intravenöse Antibiose nicht beherrschbar war. In der Konsequenz wurde eine Mastektomie durchgeführt, an die sich eine adäquate Wundheilung anschloss. Schlussfolgerungen: Auch wenn es eine täglich eingesetzte, komplikationsarme Methode ist, sollte bei der Anwendung einer Stanzbiopsie an Komplikationen wie Hämatom oder Infektion gedacht werden, gerade wenn Risikofaktoren wie Diabetes mellitus, Kortikoidtherapie oder Immunsuppression hinzukommen. Bei ausbleibender Besserung ist die operative Sanierung zu empfehlen.

work-up of suspicious breast lesions for many years. It is safe, cost effective, and the histological findings are essential for further treatment plans. However, in rare cases, complications can occur, most of which are hematoma and infection. Severe

\section{KARGER \\ Fax +497614520714 \\ Information@Karger.de}

www.karger.com (c) 2012 S. Karger GmbH, Freiburg

$1661-3791 / 12 / 0073-0240 \$ 38.00 / 0$

Accessible online at:

www.karger.com/brc
Nikola Kasprowicz, MD

Breast Center, Department of Gynecology and Obstetrics

Düsseldorf University Hospital

Moorenstraße 5, 40225 Düsseldorf, Germany

Tel. +49 211 81-17501, Fax -18483

Nikola.Kasprowicz@med.uni-duesseldorf.de 
complications are estimated to be $<1 \%$, while antibiotic treatment is necessary in only $0.15 \%$ of all CNBs [1]. In most cases, underlying conditions such as therapy with anticoagulants and diabetes mellitus contribute to the development of complications.

\section{Case Report}

A 48-year-old patient presented at our department in 8/2009 for further work-up of a routine mammography assessed as Breast Imaging Report and Data System (BI-RADS) IV bilaterally. She had no significant past medical history, but was status post open biopsy of the right breast because of a fibroadenoma (1981) and 2 reduction surgeries bilaterally in 1991 (McKissock) and 2005 (Ribeiro). There were no known malignancies in the family history.

Mammography showed a confined lobular mass of $3.5 \times 2.5 \mathrm{~cm}$ with a well-defined margin in the left upper outer quadrant, bigger in size compared to previous controls. In the right breast, 2 masses $(2.6 \times 2.4 \mathrm{~cm}$ and $1.3 \times 1.3 \mathrm{~cm}$ ) were seen, also showing progression in size. Thus, mammo- graphy was performed and verified BI-RADS IV bilaterally (fig. 1). Ultrasonographically, several lesions suspect of fibroadenoma were seen in the right breast (fig. 2, left). 2 lesions measuring approximately $10 \mathrm{~cm}$ in the left breast were regarded as fatty tissue necrosis due to previous reduction surgery. Additionally, 1 suspected cyst and 1 assumed fibroadenoma were seen (fig. 2, right). Ultrasound revealed BI-RADS IV ACR3 bilaterally. CNB was performed on 2 lesions of the right breast and on 1 of the left breast. Histology revealed fibrous mastopathy, a pseudocyst, and a fibroadenoma in the right breast, as well as a benign phyllodes tumor in the left breast (fig. 3). The latter was described as a fibroepithelial tumor with stroma poor of cells lacking nuclear atypia. Excision of the tumor was recommended.

At 10 days after biopsy, the patient developed a diffuse mastitis in the left breast. Oral antibiotic treatment with amoxicillin and clavulanic acid was initiated, in addition to conservative measures such as cooling. Because of no improvement, the patient was admitted to our ward for 5 days and received clindamycin intravenously (i.v.). Due to these measures, the mastitis showed moderate deterioration. In the following, the patient was seen weekly in our department for control of clinical symptoms and laboratory infection parameters. Magnetic resonance imaging (MRI) of the breast was initiated 1 month after the biopsy to exclude further lesions. It showed signs of infection and a lesion corresponding to the phyllodes
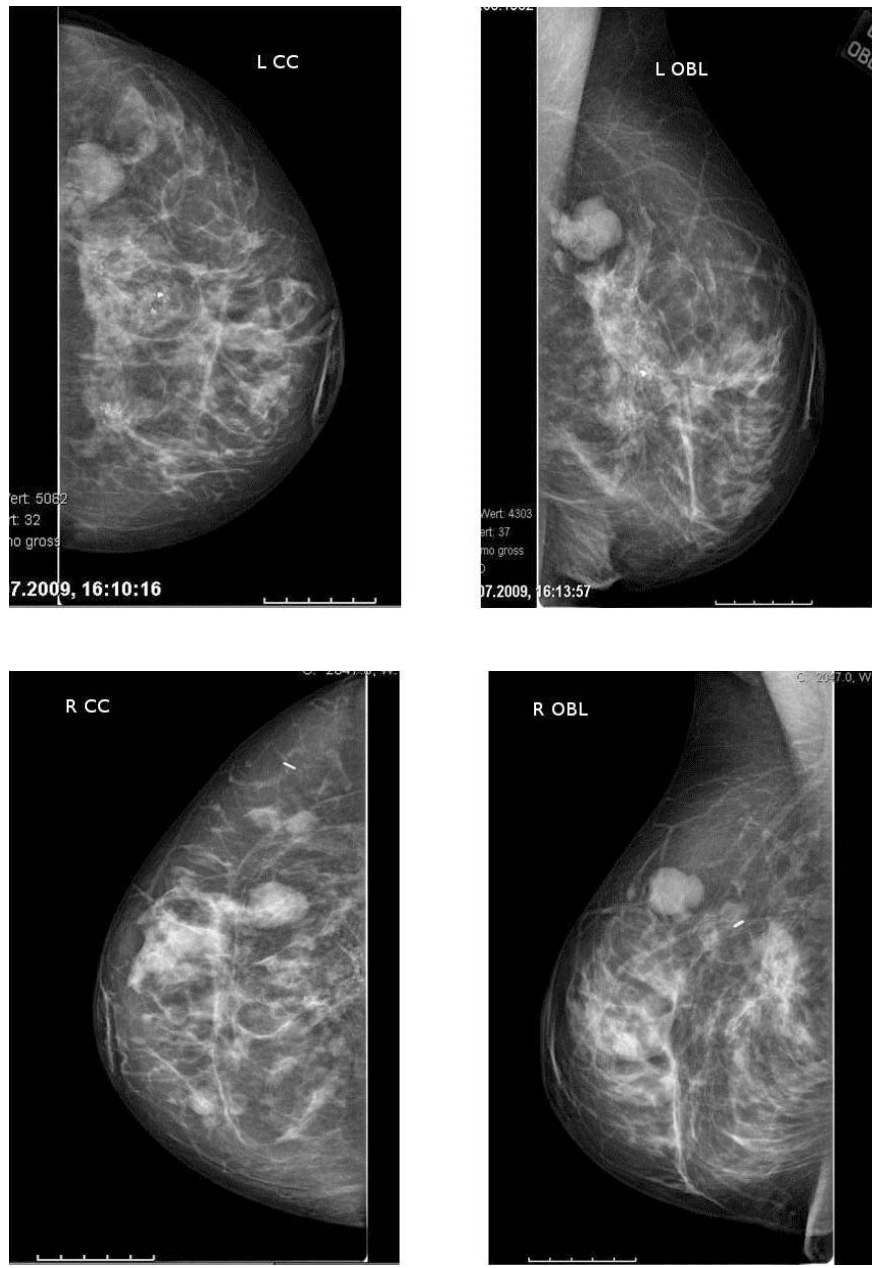

Fig. 1. (Top) Mammography of the left breast, $\mathrm{CC}$ and OBL projection: confined lobular lesion of $3.5 \times 2.5 \mathrm{~cm}$ with a well-defined margin in the upper outer quadrant and dystrophic macrocalcifications. (Bottom) Mammography of the right breast, $\mathrm{CC}$ and OBL projection: 2 masses $(2.6 \times 2.4 \mathrm{~cm}$ and $1.3 \times 1.3 \mathrm{~cm})$ showing progression in size in the upper outer quadrant.
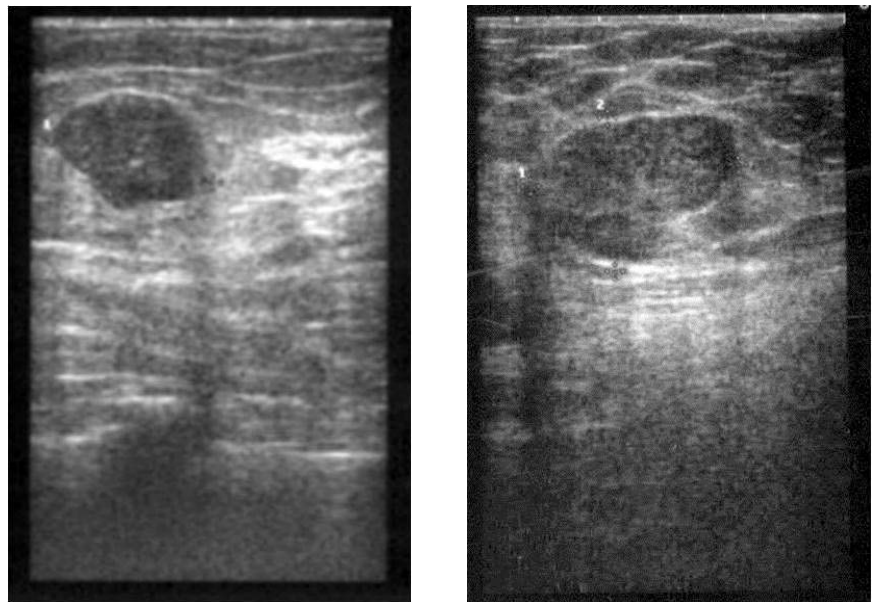

Fig. 2. (Left) US right breast: lesion suspicious of fibroadenoma. (Right) US left breast: 1 lesion suspicious of fibroadenoma; histology revealed a phyllodes tumor.

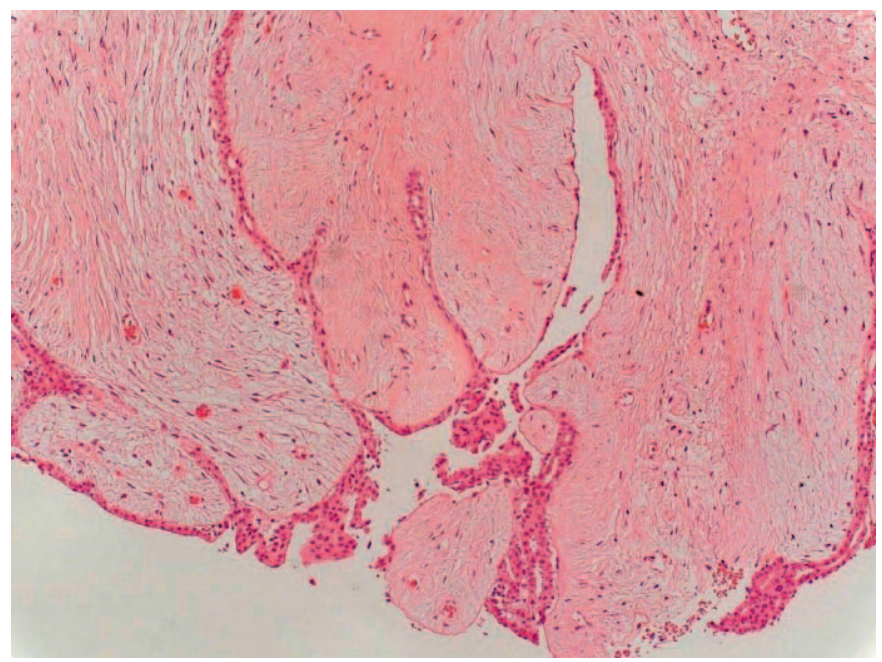

Fig. 3. Histology of the CNB of the left breast at 2 o'clock: benign phyllodes tumor $(100 \times)$. 
tumor in the left breast. In the right breast, there were several lesions suspect of fibroadenoma and one suspicious of the phyllodes tumor seen. 1 lymph node in the left axilla was enlarged (fig. 4).

However, despite the above-mentioned intensive therapeutic measures and further antibiotic treatment, the mastitis did not show any rele vant improvement over several months. At no time did an abscess

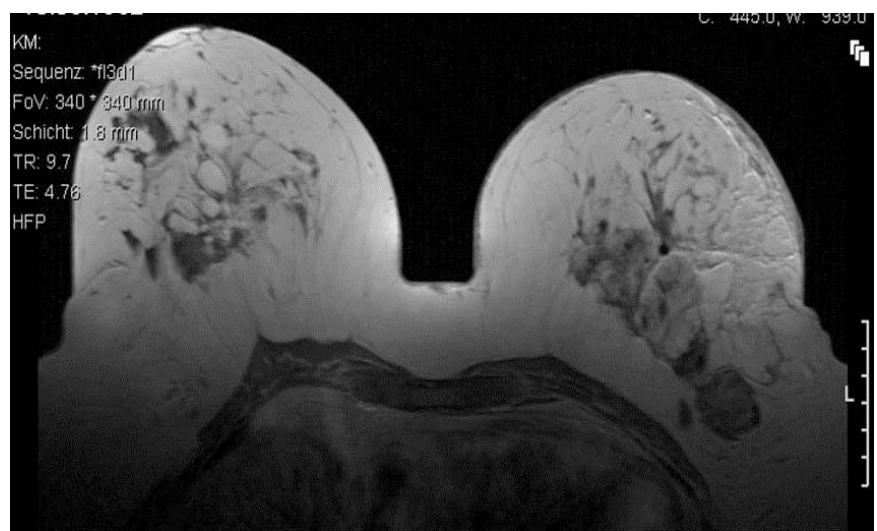

Fig. 4. MRI of the breast 9/2009: signs of infection and a lesion corresponding to the phyllodes tumor (left). Several lesions suspect of fibroadenoma and 1 with an assumed phyllodes tumor (right).

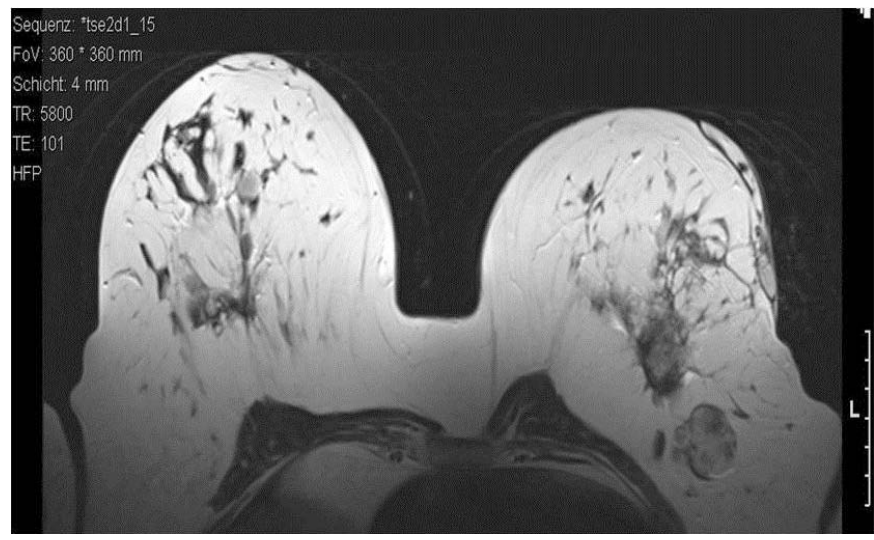

Fig. 5. MRI of the breast 3/2010: constant signs of infection and central necrosis of the fatty tissue. 1 lymph node in the left axilla showed an increase in size.

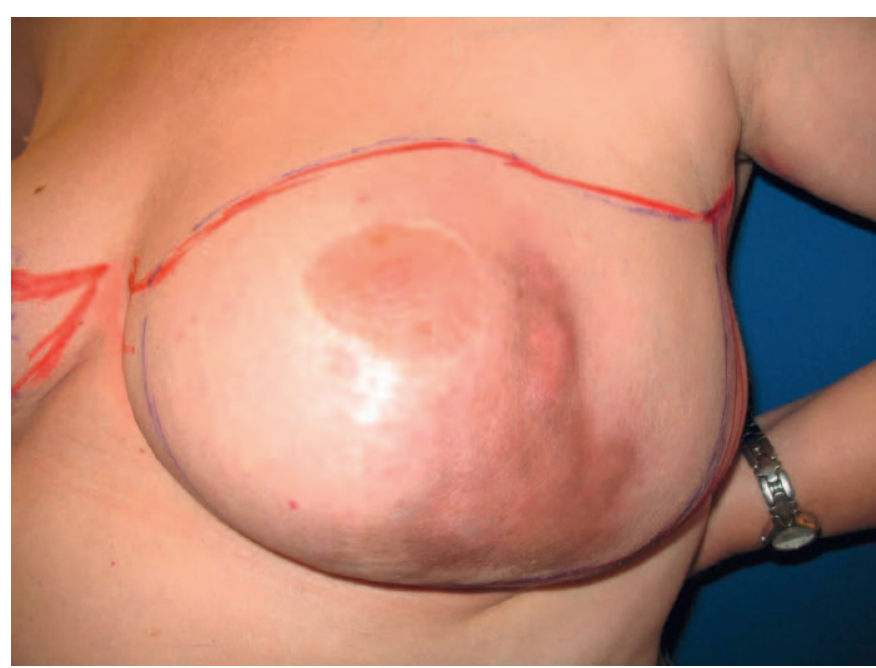

Fig. 6. Extension of the mastitis prior to surgery. develop. The patient met with 2 other specialists for a second opinion. One of them mentioned the suspicion that it could also be a malignant sarcoma. The patient was seen also by dermatologists to exclude pyoderma gangrenosum.

We recommended surgical excision of the phyllodes tumor and the suspicious lymph node on the left side, and of the fibroadenoma of the right breast. Because of her past surgical history and due to the risk of subsequent operations, the patient refused a breast-conserving surgery. She preferred bilateral mastectomy. Psychological support was provided. A second MRI was carried out prior to surgery, which showed constant signs of infection and central necrosis of the fatty tissue. The lymph node in the left axilla showed a further increase in size. There were no significant changes in the right breast (fig. 5).

Bilateral mastectomy and excision of the suspicious lymph node in the left axilla were performed 7 months after $\mathrm{CNB}$, followed by adequate wound healing (fig. 6). Histology revealed a phyllodes tumor $3 \mathrm{~cm}$ in size in the left breast, with scar tissue of $3.5 \mathrm{~cm}$ including older fatty tissue necrosis. Additionally, signs of severe chronic infection of the cutis and the subcutis were evident, in addition to dystrophic calcifications (fig. 7). Histology of the right breast detected a benign phyllodes tumor of $1 \mathrm{~cm}$ and a fibroadenoma of $2.5 \mathrm{~cm}$. The lymph node showed extensive chronic lymphadenitis with follicular hyperplasia, but no signs of malignancy.
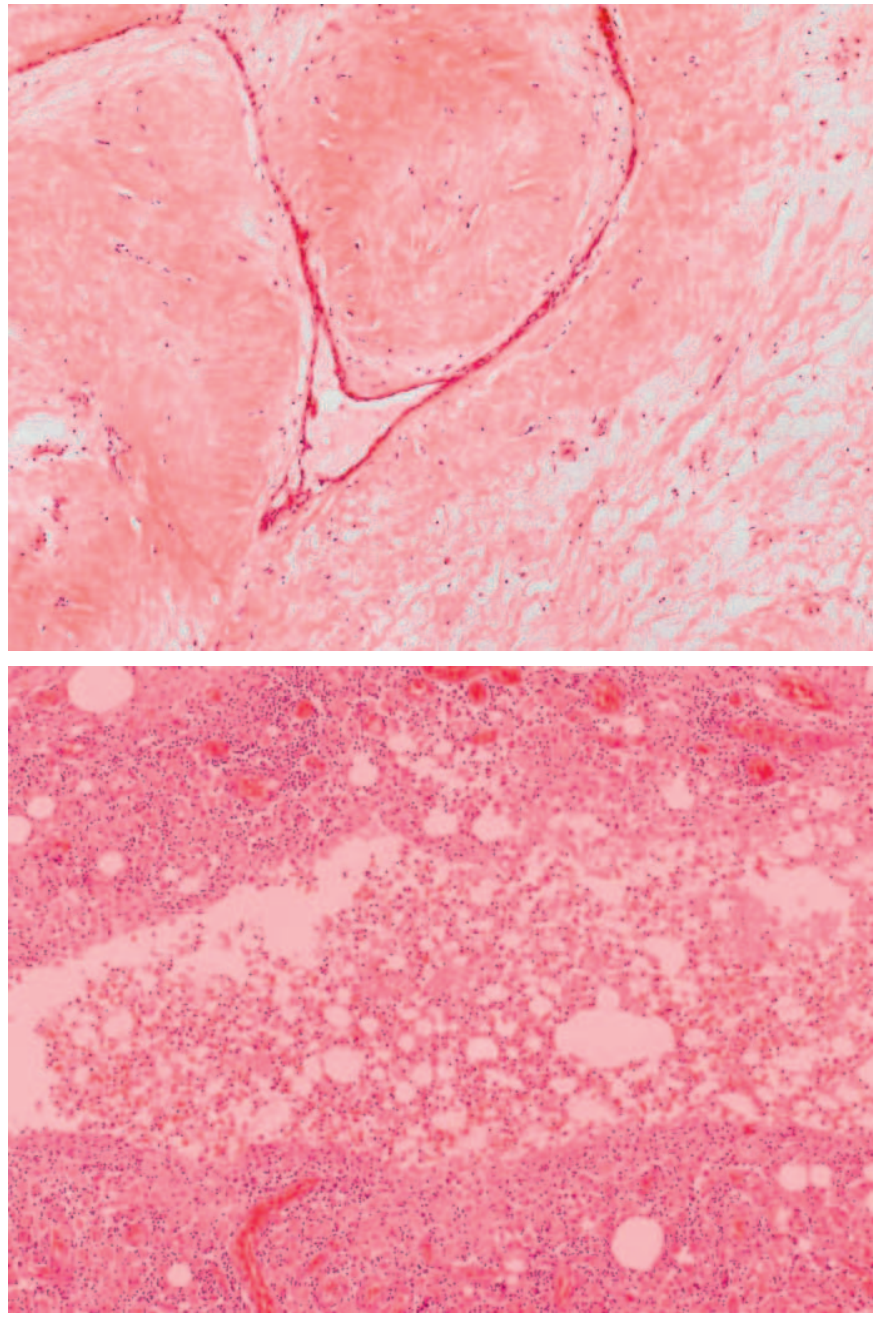

Fig. 7. (Top) Phyllodes tumor of $3 \mathrm{~cm}$ in the left breast $(100 \times)$. (Bottom) Signs of severe chronic infection $(200 \times)$. 


\section{Discussion}

Percutaneous US-guided CNB is a standard procedure in the work-up of suspicious breast lesions since the 1980s [2,3]. The biopsy can be controlled in real-time view and unerringly hits the targeted area. Histology can either exclude or confirm a malignancy. In addition, distinct histological parameters are required if neoadjuvant chemotherapy is planned.

In comparison to open surgery, the advantages of CNB include little to no scarring, reduction of costs, and avoiding subsequent open surgery if histology allows [1, 4-6]. Furthermore, a CNB does not alter the tissue as much as an open surgery for further accurate assessment by mammography or US [7].

Studies showed a sensitivity of $96 \%$ for CNB $[8,9]$. The false-negative rate in a series of 3724 biopsies was determined to be $2.5 \%$, which is consistent with other data in the literature [8-10]. However, in the majority of the cases with a falsenegative result, the tumor was found by immediate re-biopsy due to imaging-histological discordance. This emphasizes the importance of careful correlation of clinical, radiological and histological results.

The complication rates are in general very low $[1,11]$. A review showed that severe complications occur in less than $1 \%$ of cases [1]. The most common complications are hematoma and infection with an incidence of less than 1 in $1000[4,5]$. The rate of infections that required antibiotic treatment is reported to be as low as $0.15 \%$ [1]. There are single cases of necrotizing fasciitis as the most aggressive form of soft tissue infection [12]. Generally, patients at risk for infection include those with obesity or diabetes mellitus, those who are under steroid therapy, or those who are otherwise in an immunocompromised state. Interestingly, none of these predisposing risk factors apart from moderate obesity were existent in this reported case. The extensive mastitis developed after CNB and was resistant to any standard antibiotic treatment. We hypothesize adequate preparation of the biopsy site in terms of local disinfection prior to CNB. The US prior to CNB showed fatty tissue necrosis. No pathogen germ could be identified in microbiological samples and no antibiotic treatment led to a satisfying decrease in infection. These circumstances led to the assumption that the nonbacterial infection was a consequence of the impaired tissue due to the patient's previous operations. The incidence of fat necrosis as a late complication after breast reduction surgery is reported to be around $2.7 \%$ [13].

Further complications of CNB include allergy to local anesthetics [11] and the development of a milk fistula in pregnant or lactating women [14] or of a pseudoaneurysm $[15,16]$. 1 retrospective study showed no increased risk for hematoma if the patient is on anticoagulation therapy such as acetylsalicylic acid or warfarin, but bruising is significantly increased [17]. However, single reports describe extensive hematomas $[17,18]$. To conclude, although the risk for hematoma seems not to be increased, it is recommended to be alert if a patient is on anticoagulation therapy or has a known clotting disorder.

Next to pain and psychological distress after CNB [1, 19], the displacement of tumor cells along the needle track has intermittently raised concerns. In a current review on breast cancer seeding, the displacement of tumor cells was estimated to take place in around $22 \%$ of cases (ranging from $2 \%$ to $63 \%$ ) $[20,21]$. Apparently, the probability of detection of malignant cells is increased by a short interval between CNB and surgery [20]. This strengthens the thesis that these tumor cells do not survive displacement and thus do not alter the clinical outcome. According to current data, there is no significant difference with respect to the local recurrence rate or overall survival between breast cancer patients who had a CNB prior to surgery and those without $[21,22]$. To this end, $\mathrm{CNB}$ can be regarded as a safe procedure.

\section{Conclusions}

Percutaneous US-guided CNB is a standard procedure in the work-up of suspicious breast lesions. In comparison to open surgery it is faster, less invasive, and less expensive. Commonly, the complication rate is very low. The most common complications are hematoma and infection. In the presented case, the prolonged course of breast infection after CNB was not as expected. Possibly due to previous surgeries, the manipulation of the impaired tissue of the breast resulted in a mastitis that was resistant to conservative therapies. Further risk factors for subsequent infection are diabetes mellitus, steroid therapy, or immunosuppression of other origin. If this occurs, conservative treatment with antibiotics can be initiated. However, in case of missing recovery, wide surgical excision is recommended.

\section{Disclosure Statement}

The authors declare that there are no conflicts of interest.

\section{References}

$>_{1}$ Bruening W, Fontanarosa J, Tipton K, Treadwell JR, Launders J, Schoelles K: Systematic review: comparative effectiveness of core-needle and open surgical biopsy to diagnose breast lesions. Ann Intern Med 2010;152:238-246.
2 Lindgren PG: Percutaneous needle biopsy. A new technique. Acta Radiol Diagn (Stockh) 1982;23: 653-656.
3 Parker SH, Jobe WE, Dennis MA, Stavros AT, Johnson KK, Yakes WF, Truell JE, Price JG, Kortz AB, Clark DG: US-guided automated largecore breast biopsy. Radiology 1993;187:507-511. 
4 Liberman L: Centennial dissertation. Percutaneous imaging-guided core breast biopsy: state of the art at the millennium. AJR Am J Roentgenol 2000; 174:1191-1199.

5 Parker SH, Burbank F, Jackman RJ, Aucreman CJ, Cardenosa G, Cink TM, Coscia JL Jr, Eklund GW, Evans WP III, Garver PR: Percutaneous large-core breast biopsy: a multi-institutional study. Radiology 1994;193:359-364.

6 Rubin E, Mennemeyer ST, Desmond RA, Urist MM, Waterbor J, Heslin MJ, Bernreuter WK Dempsey PJ, Pile NS, Rodgers WH: Reducing the cost of diagnosis of breast carcinoma: impact of ultrasound and imaging-guided biopsies on a clinical breast practice. Cancer 2001;91:324-332.

7 Bassett LW, Mahoney MC, Apple SK: Interventional breast imaging: current procedures and assessing for concordance with pathology. Radiol Clin North Am 2007;45:881-894, vii.

$\checkmark 8$ Fajardo LL, Pisano ED, Caudry DJ, Gatsonis CA Berg WA, Connolly J, Schnitt S, Page DL, McNeil BJ: Stereotactic and sonographic largecore biopsy of nonpalpable breast lesions: results of the Radiologic Diagnostic Oncology Group V study. Acad Radiol 2004;11:293-308.
9 Youk JH, Kim EK, Kim MJ, Oh KK: Sonographically guided 14-gauge core needle biopsy of breast masses: a review of 2,420 cases with long-term follow-up. AJR Am J Roentgenol 2008;190:202-207.

10 Youk JH, Kim EK, Kim MJ, Kwak JY, Son EJ: Analysis of false-negative results after US-guided 14-gauge core needle breast biopsy. Eur Radiol 2010;20:782-789.

11 Harvey JA, Moran RE, DeAngelis GA: Technique and pitfalls of ultrasound-guided core-needle biopsy of the breast. Semin Ultrasound CT MR 2000;21:362-374.

12 Flandrin A, Rouleau C, Azar CC, Dubon O, Giacalone PL: First report of a necrotising fasciitis of the breast following a core needle biopsy. Breast J 2009;15:199-201.

13 Mizgala CL, MacKenzie KM: Breast reduction outcome study. Ann Plast Surg 2000;44:125-133.

14 Schackmuth EM, Harlow CL, Norton LW: Milk fistula: a complication after core breast biopsy. AJR Am J Roentgenol 1993;161:961-962.

15 El Khoury M, Mesurolle B, Kao E, Mujoomdar A, Tremblay F: Spontaneous thrombosis of pseudoaneurysm of the breast related to core biopsy. AJR Am J Roentgenol 2007;189:W309-W311.
6 Erdil I, Dursun M, Salmaslioglu A, Ozcinar B, Acunas G: Pseudoaneurysm in the breast after core biopsy: Doppler US and MRI findings. Breast J 2010;16:427-429.

17 Somerville P, Seifert PJ, Destounis SV, Murphy $\mathrm{PF}$, Young W: Anticoagulation and bleeding risk after core needle biopsy. AJR Am J Roentgenol 2008;191:1194-1197.

18 Yap LP, Rouse H, Cawson J: An extensive breast hematoma following stereotactic 9 gauge vacuum assisted large-core biopsy. Breast J 2010;16:199200.

19 Maxwell JR, Bugbee ME, Wellisch D, Shalmon A, Sayre J, Bassett LW: Imaging-guided core needle biopsy of the breast: study of psychological outcomes. Breast J 2000;6:53-61.

20 Diaz LK, Wiley EL, Venta LA: Are malignant cells displaced by large-gauge needle core biopsy of the breast? AJR Am J Roentgenol 1999;173:1303-1313.

21 Liebens F, Carly B, Cusumano P, Van BM, Beier B, Fastrez M, Rozenberg S: Breast cancer seeding associated with core needle biopsies: a systematic review. Maturitas 2009;62:113-123.

22 Fitzal F, Sporn EP, Draxler W, Mittlbock M, Taucher S, Rudas M, Riedl O, Helbich TH, Jakesz $\mathrm{R}$, Gnant M: Preoperative core needle biopsy does not increase local recurrence rate in breast cancer patients. Breast Cancer Res Treat 2006;97:9-15. 